\title{
10
}

\section{CHINESE GREEN ENERGY PROJECTS IN SUB-SAHARAN AFRICA}

\author{
Are there co-benefits?
}

\author{
Padmasai Lakshmi Bhamidipati, Cecilia Gregersen, Ulrich \\ Elmer Hansen, Julian Kirchherr, and Rasmus Lema
}

\begin{abstract}
Investments in renewable energy are increasing rapidly in sub-Saharan Africa. An interesting trend to note is the rapid increase and likely future growth of Chinese involvement in large-scale renewable-energy infrastructure projects. Our focus in this chapter is to determine the extent of co-benefits created when renewable-energy projects are developed by Chinese investors. For this, we undertake an in-depth micro-level analysis of three Chinese renewable-energy investment projects in hydro (Ghana), wind (Ethiopia), and solar photovoltaic (PV) (Kenya), based on primary data. Overall, we find evidence of 'bounded benefits'. On the one hand, we can identify some newly created jobs, linkages generated with actors in local systems of production, and training activities involving local staff. On the other hand, the extent of these benefits is very limited. The results suggest that policymakers should be wary of overly optimistic expectations when it comes to assessing the co-benefits of renewable energy projects in the context of scarce pre-existing capabilities. However, the adoption of pro-active strategies and the implementation of carefully designed policies can increase the local economic co-benefits. ${ }^{1}$
\end{abstract}

\section{Introduction}

The electricity generating capacity in sub-Saharan Africa (SSA) will double over the next 20 years, with renewables accounting for three-quarters of new generation, the majority of that coming from solar, hydro, and wind (IEA, 2020). The purpose of this book chapter is to explore to what extent and under what conditions these massive investments in renewable energy (RE) have economic co-benefits. Additional benefits going beyond countering climate change in 
sub-Saharan Africa include job creation, improvement of local skills and creation of income-generating activities. The RE sector can become an integral part of local economies, integrated both through upstream supply chain, such as production of equipment components, and downstream energy related services, such as maintenance (IRENA, 2013, p. 15; see also Sperling, Granoff and Vyas, 2012).

In this chapter we focus on investments made by China as it accounts for the single largest investment portfolio in SSAs power sector. ${ }^{2}$ According to the International Energy Agency (IEA, 2016, p. 7), projects in which a Chinese firm is the main contractor alone account for $30 \%$ of new capacity additions in SSA; of these projects, $56 \%$ are in renewable energy, with the vast majority being in hydropower, but increasingly also in wind and solar energy. Insights from other infrastructure, utility, and resource-extraction sectors in SSA suggest that China is pursuing a specific Chinese model of investments consisting of enclave characteristics, including finance, turnkey project development, and imports of labour and equipment from China (Kaplinsky and Morris, 2009; Sanfilippo, 2010; Wegenast et al., 2019). Hence our focus in this chapter is to what extent economic co-benefits arise in sub-Saharan Africa when renewable-energy projects are developed by Chinese investors: what is the potential for benefiting from Chinese renewable-energy investments in terms of employment, localisation of the value chain and technological learning? In order to seek insights into this question, we focus on investments in hydro, wind, and solar energy for electricity generation.

Despite the increasing attention paid to Chinese renewable-energy investments in SSA and the economic opportunities associated with them, there are few studies, let alone systematic analyses, in the existing literature (Shen and Power, 2016). In addition, there is very little evidence of the real economic opportunities associated with green investments and policies in low and lowermiddle income countries. In this chapter, we undertake an empirical examination of three specific Chinese projects in hydro, wind, and solar energy. We also address the research gap by gathering insights about economic opportunities and developmental effects from three case studies of frontrunner green energy projects in SSA. ${ }^{3}$ By providing in-depth analysis of co-benefits in terms job creation, value-chain localisation, and capability-building, we hope to stimulate an informed discussion of the conditions and policy measures which may maximise the local benefits of these investments.

We develop a conceptual framework and employ co-benefits approach to unravel the three case studies and the explanatory determinants for the respective outcomes. While the analytical framework is elaborated in detail in another article (Lema, Fu, and Rabellotti, 2020), we focus mainly on the empirical findings in this book chapter. In the next section, we highlight China's involvement in the renewable energy deployment in SSA, followed by in-depth findings from the case studies in detail. This is followed by a section which analyses the explanatory factors and summarises the co-benefits in a comparative way to gauge the similarities and differences among the three cases. The chapter ends with a conclusion and policy implications. 


\section{China's involvement in renewable energy deployment in SSA}

This section provides an overview of China's involvement in renewable energy deployment in sub-Saharan Africa in relation to the three technologies discussed in this article. Discussing the patterns of capital and technology flows from China allows us to examine the macro-evidence for the existence of a 'Chinese model' of green energy investments. The purpose is to provide a backdrop for the project-level analyses in subsequent sections.

\section{China's overall role in the SSA energy sector}

Shen (2020) estimates that Chinese finance for the energy sector in Africa, including North Africa, amounted to a total of more than USD 30 billion over the sixteen-year period from 2000 to 2016, but this includes all energy sources, both black and green. However, according to the IEA (2016), in an analysis of Chinese greenfield energy investment projects which had been completed, were under construction, or were planned for completion over the 2010-2020 period, 56\% of Chinese energy-generation projects were found to use sources of renewable energy. The total investments involved amounted to USD 13 billion across 37 countries.

We analysed the available data on the installed capacity in SSA across the three energy sources. (IRENA, 2013, 2019). In the hydropower sector, Chinese investors accounted for $60 \%$ of investments in sub-Saharan projects. The Chinese are also significantly involved in both the solar PV investments (108 MW in 2009 to $6.1 \mathrm{GW}$ in 2018) - which surpassed investments in hydropower for the first time in 2019 - and the wind-energy sector $739 \mathrm{MW}$ in 2009 to $5.5 \mathrm{GW}$ in 2018), which is forecast to grow rapidly in SSA, in particular in countries with high altitudes or locations at some distance from the equator (IEA, 2016, 2020). However, there are no data sources which can give a complete picture of the relative degrees of Chinese involvement across the three technologies (Shen, 2020).

\section{Roles of Chinese actors as financiers, EPC contractors, and technology suppliers}

This section analyses the role of various Chinese actors in the development of hydropower, solar PV, and wind-power projects, focusing specifically on:

i) Financial institutions - the Export-Import Bank of China is by far the main investor in projects constructed by Chinese contractors, providing finance to more than $60 \%$ of the projects analysed in IEA (2016). The main investment model is based on preferential loans and export credits provided to project developers. In addition, direct equity-based investments, commercial loans, and grants are also provided, in particular from the financial institutions mentioned in Table 
10.1. Financial institutions are powerful actors in the transnational investment-production complexes in which green energy infrastructure projects are embedded, and they may specify 'foreign content requirements' involving Chinese Engineering, Procurement, and Construction (EPC) contractors and technology providers as part of financing deals.

ii) EPC contractors - The main Chinese contractors involved in renewableenergy projects in sub-Saharan Africa typically include large state-owned enterprises (SOEs): 90\% of the power projects analysed in IEA (2016) are being contracted and constructed by Chinese SOEs (see Table 10.2). The remaining $10 \%$ of these projects are being constructed by private Chinese developers specialising in large-scale infrastructure, construction, and civilengineering projects in the energy sector. ${ }^{4}$ As already mentioned, under EPC contracts, Chinese developers are responsible for all aspects of the project, from the initial feasibility stage via plant engineering and the subcontracting of components and related services to the plant's final commissioning. EPC is thus instrumental in selecting technology providers.

iii) Technology providers - Given an increasingly saturated domestic market and fierce competition in the European and US markets, Chinese technologyproducing companies, such as those mentioned in Table 10.2, have increasingly moved into sub-Saharan Africa (Shen, 2020).

Table 10.2 draws on the available data to show the changes in exports of renewable-energy technology from China to sub-Saharan Africa over two five-year

TABLE 10.1 Key Chinese financial institutions, EPC contractors, and technology suppliers involved in the green energy sector in sub-Saharan Africa

\begin{tabular}{|c|c|c|c|}
\hline & Finance & EPC contractors & Technology suppliers \\
\hline Hydro & $\begin{array}{l}\text { - China Export-Import } \\
\text { Bank (China Exim } \\
\text { Bank) } \\
\text { - Chinese Development } \\
\text { Bank (CDB) } \\
\text { - Sinosure }\end{array}$ & $\begin{array}{l}\text { - } \text { Sino Hydro } \\
\text { - PowerChina } \\
\text { Resources } \\
\text { - Three Gorges } \\
\text { Corporation }\end{array}$ & 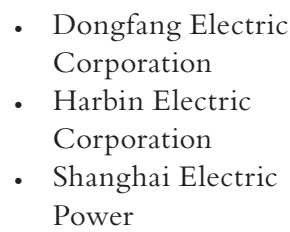 \\
\hline Wind & $\begin{array}{l}\text { - Industrial and } \\
\text { Commercial Bank of } \\
\text { China (ICBC) } \\
\text { - Bank of China (BoC) }\end{array}$ & $\begin{array}{ll}\text { - } & \text { CGC Overseas } \\
& \text { Construction Group } \\
\text { - Hydro China } \\
\text { - Longyuan Power } \\
\text { Group }\end{array}$ & $\begin{array}{l}\text { - Goldwind } \\
\text { - Sany } \\
\text { - Sinovel }\end{array}$ \\
\hline Solar & & $\begin{array}{l}\text { - China Jiangxi } \\
\text { Corporation } \\
\text { - Powerway } \\
\text { - Beijing Xiaocheng }\end{array}$ & $\begin{array}{ll}\text { - } & \text { JinkoSolar } \\
\text { - } & \text { Yingli } \\
\text { - } & \text { JA Solar }\end{array}$ \\
\hline
\end{tabular}

Source: authors, adapted from Chirambo (2018), Shen and Power (2016), and Tan-Mullins, Urban, and Mang (2017). 
TABLE 10.2 Exports of hydro, wind, and solar equipment from China to Africa 2006-2016 (USD million)

\begin{tabular}{lrrr}
\hline & $2006-2010$ & $2011-2016$ & \multicolumn{1}{c}{ Total } \\
\hline Hydro & 2,647 & 9,824 & 12,471 \\
Wind & 1,807 & 532,189 & 533,996 \\
Solar & 41,706 & 393,058 & 434,764 \\
Total & 46,16 & 935,071 & 981,231 \\
\hline
\end{tabular}

Source: authors, based on COMTRADE (HS codes: 841011, 841012, 841013, 850231, and 854140). *Export of hydraulic turbines and water wheels from China to Africa.

periods. There have been massive increases in exports since 2010 in all three sectors. Hydro-technology exports and imports are relatively low compared to wind and solar because core technology only constitutes a relatively small share of the overall capital expenditure in hydro projects. However, China-Africa trade in hydro-technologies like turbines more than tripled in the second fiveyear period when compared to the first. Nonetheless this increase is nothing like as dramatic as the increase in wind and solar, both of which are growing exponentially. These data show how recent a phenomenon the trade in renewable energy from China to Africa is and how quickly it is growing.

To summarise, the increasing influence of China in the renewable-energy sector in sub-Saharan Africa can be observed across the three renewable-energy sub-sectors analysed in this article. Interestingly, we see a tendency for Chinese investors and contractors to supply projects on a turnkey basis delivered as a bundled package comprising a considerable representation of Chinese investors, engineering companies, and technology suppliers. A possible reason for the development of this Chinese model may be the nature of China's funding-support requirements, which stipulate that investors are eligible for export credits only if the equipment used is manufactured in China.

The following section draws on primary data to examine the key factors and indicators developed for this analysis (in the next section). Three sub-sections describe each of the case-study projects in turn. Table 10.3 provides an overview of the key actors in these three projects across both the stage of infrastructure delivery (engineering, procurement, construction, and various sub-tasks) and the stage of service delivery (operation, maintenance, and distribution). These are preceded by an initiation stage focusing on entrepreneurial development, and the negotiation stage, which is important because it defines the nature and scope of the subsequent steps. 
210 Padmasai Lakshmi Bhamidipati et al.

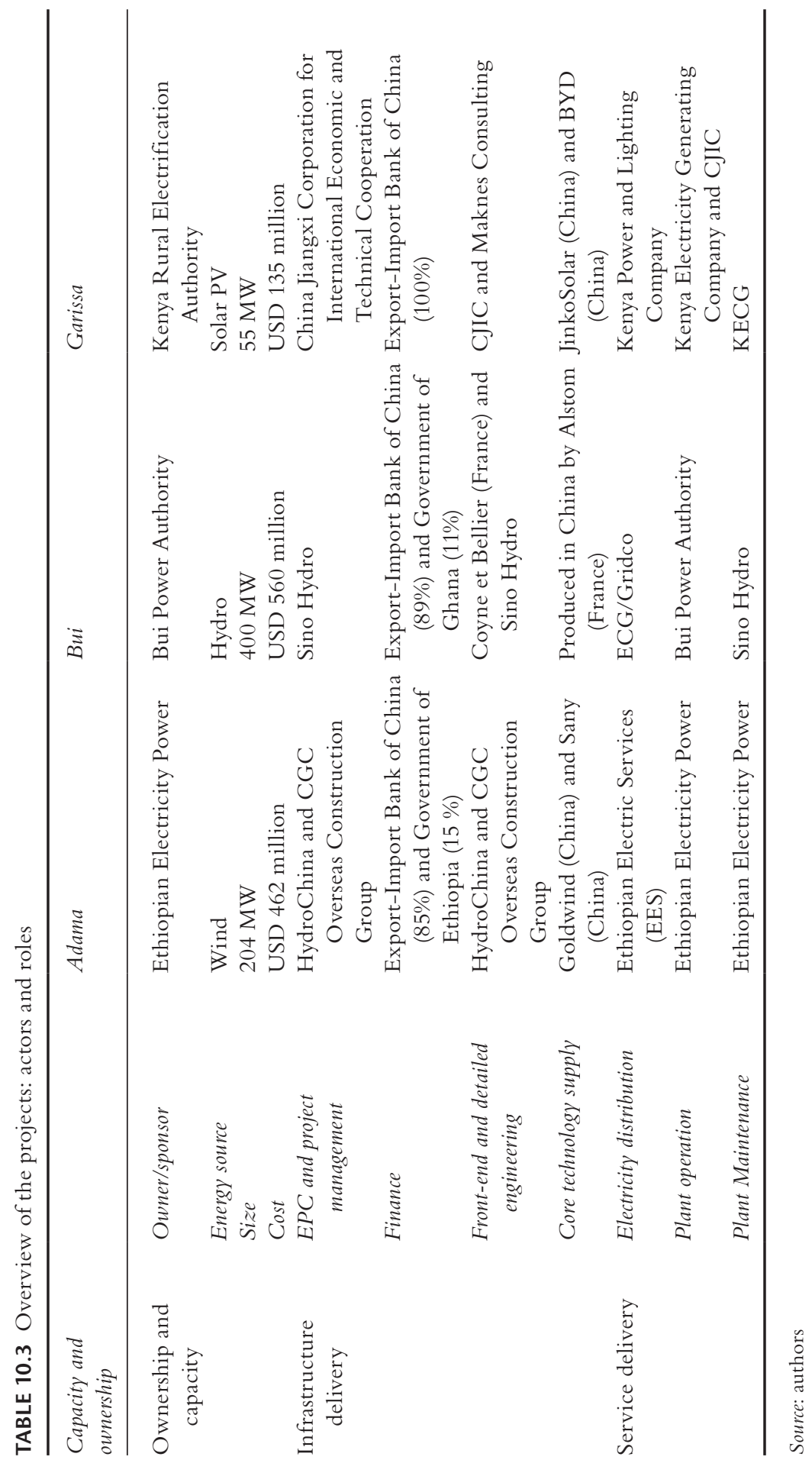




\section{Findings from the case studies}

\section{Adama wind power project}

The Adama wind power project consisted of two phases of planning and construction by a joint venture between Chinese turnkey EPC contractor HydroChina and the CGCOC group, a Chinese construction company, for Ethiopian Electricity Power (EEP), the project owner. The first phase included the installation of $51 \mathrm{MW}$ of wind power and was finalised in 2012. The second phase, Adama II, included the installation of $153 \mathrm{MW}$ and was commissioned in 2015.

The types of jobs created in the Adama project are directly linked to the financing agreements, which specified that Chinese technology was to be used in the project. The turnkey contract held by HydroChina-CGCOC covered the majority of the value chain for the project, from its design and construction to handover training. Local jobs in project construction totalled 1000 across the two phases compared to approximately 400 jobs held by Chinese employees. The contract between EEP and HydroChina stated that unskilled labour should be recruited locally and that using staff and skilled labour from sources within Ethiopia was to be encouraged. However, the large number of Chinese employees involved during this phase suggests that the job types varied, and that project management was to a large degree carried out by Chinese nationals. The key project-management personnel included approximately 13 Chinese staff for phase II, ten of whom had already worked on phase I.

Local content in the project was limited to the minimum involvement of local firms in the supply of construction materials such as concrete, while the stateowned shipping company was involved in the transportation of wind-turbine components. All imported equipment, materials, and construction equipment were exempt from customs duties, value added tax, additional taxes, and the withholding tax. Furthermore, there was only minimal involvement by local communities in respect of deciding compensation for the temporary and permanent loss of farmland in order to build the wind farms and the necessary access roads. Beyond the access roads and water pumps, other social development projects were not deemed to be required. HydroChina held multiple information sessions and seminars to educate local residents on the impacts of wind farms.

In respect of technological learning, the investment model, designs, and blueprints for the project were developed independently by HydroChina and CGCOCC. All permanent equipment for the project was sourced and imported from Chinese companies - the unit transformer, 33KV cabinet, main transformer, circuit breaker, grounding transformer, SCADA system, and communication equipment - which constrained local learning. However, a team of 17 employees from Ethiopian universities was engaged by EEP to monitor implementation of the project during the construction stage and administer the contract. These employees were engaged to carry out a number of supervisory tasks, including 
reviewing micro-siting and layout designs, supervising the civil infrastructure, construction and erection of the wind turbines, and preparing acceptance certificates and project manuals. The university consultancy arrangement was the result of a national strategy to involve universities in projects in order to facilitate technology transfers and capacity-building. The project owner's knowledge accumulation was focused on Operations \& Maintenance (O\&M) related technological learning, while the university consultancy was specifically tasked with acquiring knowledge in project management, the implementation of construction contracts and ultimately building capacity for the manufacture of the components of wind-power technologies.

In summary, the Adama project is a case of medium co-benefit creation, with moderate local job creation in low-skilled construction and O\&M, some local sourcing of peripheral services, and the critical involvement of actors in the local knowledge system. There was some technological learning, but it was still rather restricted. Most learning was confined to service delivery domains, with little to no learning in the infrastructure delivery domain. The main explanation for the economic co-benefits observed here is to be found in the semi-strategic stance adopted by the Ethiopian government, with a deliberate and explicit effort to obtain useful knowledge from the project implementation process. The nature of the technology adopted and the absence of a corresponding local supply base meant that there were few possibilities for local inclusion in the manufacturing chain, but there was a possibility for further inclusion in services, such as plant construction, turbine assembly, and installation. However, the project was undertaken mainly as a 'bundled' model with end-to-end services delivered by the Chinese consortium. This model was chosen through non-competitive and direct negotiations between the local government and the Chinese developers. Policy was the most decisive factor in securing some benefits, but it was not extended beyond involving key knowledge actors, so that further potential economic activities were not localised.

\section{The Bui Dam hydropower project}

Construction of the Bui Dam - with Sinohydro, a Chinese state-owned enterprise that is the world's largest dam-builder with a global market share of more than $50 \%$ in charge of its execution - started in 2006. The contract with Sinohydro was a turnkey or EPC contract, which meant that Sinohydro was only in charge of its construction and not its operation. The Bui Dam, a rollercompacted concrete (RCC) gravity dam in Ghana with a capacity of $400 \mathrm{MW}$, was completed in 2013, the entire dam (including turbines, powerhouse etc.) and its operation being turned over to the Bui Power Authority (BPA) ${ }^{5}$ upon completion of the project.

Formally, strategic oversight of the project lay with the Ghanaian Ministry of Energy (MoE) and the operational oversight with the Bui Power Authority (BPA). A nuanced understanding of mega-dam construction is needed to fulfil 
such oversight duties sufficiently (Flyvbjerg, Holm, and Buhl, 2002). However, various interviewees suggested that Sinohydro's reporting to the MoE and the BPA was relatively sporadic and at times incomplete, due to limited capacity within MoE.

In respect of jobs, of the 1,836 workers employed at the Bui Dam construction site, as many as $91 \%$ were Ghanaian, the project thus providing 'temporary employment for roughly one out of 20 workers in the Tain District' where the project is located. On-the-ground management of the project, however, was exclusively Chinese. Informants suggested that importing relatively low-skilled construction workers from faraway China instead of hiring them locally, with only the little training required by them, would increase the project's costs. Around 50 Ghanaian staff, employed by BPA, are now involved in the operation and maintenance of the project.

With regard to local content, most material-processing content and associated sourcing needed for the dam, mostly concrete, were sourced locally. The exact percentage of local content going into this project is difficult to establish, but one informant estimated that at least $60 \%$ of this project consisted of local content. This high share of local content was to some extent policy-driven, as a clear local-content policy guides investment in the country. While overall local content provision was significant, it is also clear that the more sophisticated provision of products and services was retained by Sinohydro, which, for example, procured three $133 \mathrm{MW}$ hydro turbines from the French company Alstom's factory in China.

With respect to technological learning, we distinguish between learning related to construction and to operation. While the construction of a large dam is a complex endeavour, with hydropower dams completed post-2000 facing an average cost overrun of $33 \%$ and an average schedule overrun of $18 \%$, its operation is relatively uncomplicated. BPA was expected to be able to operate the dam upon its completion. However, this turned out not to be the case. Sinohydro was re-engaged to ensure that major maintenance was carried out (also reported by GhanaWeb, 2017). This suggests that little technological learning took place on the Ghanaian side in connection with the project's maintenance when it was constructed. Also, Sinohydro did not transfer any significant knowledge and expertise regarding the technology to the Ghanaians. Therefore, despite the local employment during the O\&M stage, the locals struggled to carry out the various maintenance tasks due to which Sinohydro were rehired again for capacity-building.

To summarise, this is a case of low co-benefits, with employment of workers in Bui district during construction, but with little national impact. Limited technological learning took place, mostly confined to the operations part of service delivery and not including maintenance or construction, but there was a significant degree of local sourcing of construction materials. The main explanation for the identifiable economic co-benefits is the nature of the technology, where project management is highly complex, where only a few steps in infrastructure 
delivery in the value chain can be carried out remotely, and where construction needs to be localised. However, due to the absence of independent local firms, in Ghana these steps were carried out by Chinese firms. The project contract was directly negotiated between the Ghanaian government and the Chinese developers. In the absence of a strategic vision on the part of the government, the EPC's full-package provision left very little room for localisation and learning in this deal. The core insight from the Bui Dam case with regard to co-benefits from the perspective of the Ghanaian stakeholders is thus that the most crucial long-term co-benefit, technological learning, was not facilitated by Sinohydro. However, those co-benefits that are frequently discussed in the popular press, namely local content, local participation, and job creation, were more substantial.

\section{The Garissa Solar PV project}

The Garissa PV project is the first grid-connected solar project in Kenya, with a capacity of $54 \mathrm{MW}$. It was conceived by China (the Jiangxi Province representatives - JPR), along with Kenya (Ministry of Energy - MoE). The lead project developers (in particular, JPR) also facilitated securing the full project finance via China's Exim Bank, provided as a concessional loan. The project, commissioned in 2016, is administered and owned by the Rural Electrification and Renewable Energy Corporation (REREC). ${ }^{6}$ While there is a FiT in place in Kenya to attract private investment and standardise tariffs, this was circumvented, and direct negotiations were used instead.

The choice of technology suppliers for the Garissa project was determined by the tied financing agreement, which mandated the use of Chinese technology. The JPR recruited their own state-owned enterprise, the China Jiangxi Corporation for International Economic and Technical Cooperation (CJIC), as the lead EPC and signed a contract with Jinko Solar to supply panels, and with Byd for inverters. CJIC also subcontracted two Chinese companies for project design and civil works. After the project's completion, there was a brief handover period from CJIC for the O\&M, with a service agreement of two years, to the Kenya Electricity Generation Company (KenGen), responsible for undertaking O\&M at the plant and contracted by REREC.

While there was no explicit strategy, the priority for local jobs was subject to a verbal agreement between REREC and CJIC. The overall project management was carried out by Chinese nationals, while nearly $85 \%$ of the workers employed during the project's construction were Kenyan nationals. However, most of them were hired on a casual basis, without formal contracts. During the construction period, nearly 300 to 350 Kenyan workers were employed. Of this, a majority took on low-skill tasks as carpenters, masons, drivers, manual lifters, and security guards, and they were involved in constructing the office buildings, lifting solar panels, and performing such manual tasks. The rest were engaged in semi-skilled tasks, including the installation of solar panels, electrical work, and steel work. In this period, nearly 75 Chinese employees were engaged in preparing steel 
structures, supervising tasks, operating JCB machines, and performing electrical tasks. During the operational phase, nine O\&M engineers are employed on a contract basis, of whom five are Kenyan nationals and four are Chinese, forming a team working in a similar capacity. ${ }^{7}$

The bundling of finance with an EPC contract left relatively limited scope for local content. The sub-contractors included mainly Chinese companies. For civil works, a local Kenyan company was contracted to provide manpower during the construction phase. While Kenya has a sizeable number of solar PV companies, they are focused mainly on off-grid systems and small-scale PV installations. A few companies are gradually scaling up in the hope of obtaining sub-EPC contracts for large projects, but there are limitations still pertaining to project design, sizing systems optimally, and handling O\&M tasks.

In terms of local technological learning, there was only a limited transfer of core technological knowledge, since all the permanent equipment for the project was imported as embodied knowledge from China, including solar panels, accessories, electrical equipment, the control system, and construction tools. Some construction equipment was sourced locally in Kenya, including electrical cabinet boxes, switch boxes, and circuit breakers. While core technological learning was limited, there was learning in other areas, including 'systems' design and operations. REREC engaged a Kenyan firm, Maknes Consulting Engineers, to oversee technical activities in the project. Maknes played a supportive role in reviewing the project drawings and O\&M manuals, supervising the installation work, and overseeing technical progress. Reportedly, the tasks carried out by Maknes in the Garissa project were similar to those undertaken in other projects, albeit not on this scale. In other words, local knowledge acquisition regarding large-scale PV was deliberately designed into the project, which may be relevant to future projects.

To summarise, this is a case of low co-benefits. Although local job creation was significant (of the three projects, the highest per megawatt installed), local equipment provision and skills and knowledge transfer were limited and peripheral. Although one local engineering firm became involved in the infrastructure delivery process, gaining experience relevant to project execution, local learning was mainly confined to O\&M. The main explanation for the limited economic co-benefits that were observed in this case are to be found in the institutional arrangements surrounding the project, with limited strategic intent evoked by local policymakers in relation to its organisation. The project was directly negotiated and involved a consortium model involving Chinese firms, contractors, and financiers with limited involvement by local actors. Although local solar firms could arguably have taken responsibility for parts of the project's construction, this was precluded by the 'tied finance' underpinning the project. 


\section{Economic co-benefits and their determinants}

The three projects differ significantly in their technical nature, but it is relevant to bring them together for analysis and comparison. In this final analytical section, we start by providing an overview of the identification of co-benefits before proceeding to an explorative discussion of the determinants of these benefits.

\section{The nature of inbound flows of capital and technology from China}

The nature and flows of capital and technology were important influencing factors when it comes to the realisation of co-benefits. They differ greatly with respect to labour intensity, capital requirements and complexity involved in each of the projects, a finding aligned with the previous literature, which highlighted that industry localisation effects are highly technology-specific (Schmidt and Huenteler, 2016). For example, the relatively high degree of local content in the Bui case can be explained by the high transportation costs of cement for construction and the need to produce the cement on site.

However, in none of the three cases was the choice of technology for the project rooted in such deliberations or overall national energy plans (with the partial exception of the Bui Dam). On the contrary, the interviews suggest that technology selection was heavily influenced by the Chinese lead agents involved, who had their own technological preferences, in conformity with the previous literature (Ajakaiye and Kaplinsky, 2009; Kaplinsky and Morris, 2009). The analysis suggests that benefits are constrained by a dominant pattern of 'tied financing' associated with such chains, and it confirms the role of the nature of finance.

The case of Garissa showed how Jiangxi Province initiated the discussions and favoured its own state-enterprise, CJIC, while sourcing finances from China's Exim Bank. Similarly, the Adama case showed how the major actors in the project, EEP and HydroChina/CGOCCC as the EPC contractors, negotiated the contract and all contingent decisions. In the Bui case, the Chinese technology suppliers and EPC contractors also followed the Chinese investors in a tied-finance agreement. It was a requirement that investors had to produce the equipment in China in order to be eligible for export support. A non-Chinese contractor (Alstom) also received economic benefits because the equipment used in the project had been produced in China. Moreover, the contractual arrangements for this project, using an EPC contract, could have been more advantageous to the Ghanaian stakeholders, with the MoE and BPA likely to benefit much more from a build-operate-transfer (BOT) contract, which would have legally obliged Sinohydro to build the capacities needed for BPA to maintain the Bui Dam.

\section{Local institutional and economic conditions}

The analysis also suggests that local conditions - local deployment models, industrial policies, the domestic supply base, and local capabilities - significantly 
influence the nature of both the project and associated co-benefits. It is relevant to note that the projects analysed were negotiated in the context of weak institutional regimes, or even 'institutional voids' (Silvestre, 2015), when it comes to the host economy deployment policy model for renewable energy. This meant that projects were negotiated 'ad hoc' even when there was a FiT policy in place, which was eventually circumvented (the Garissa case), or there were initially intentions regarding local content, which ultimately could not be met (the Bui case).

The policy stance is a key variable and can make the difference between 'naturally occurring co-benefits' and 'induced co-benefits'. The majority of identified co-benefits are of the former type (e.g., sourcing local cement in the case of hydro), but some case material also points to the latter occurring.

The industrial policy approach also influences the associated co-benefits, confirming insights in the existing literature (Baker and Sovacool, 2017; McCrudden, 2004; Power et al., 2016). A more deliberate and strategic form of engagement means a greater likelihood of local capacity-building. The best example of this is the wind project in Adama, where explicit attention was paid to technological, learning, and supply-chain development during the contracting stage. As a counterpoint, the Garissa project was implemented in the context of a laissezfaire regime that entailed limited local jobs in the supply chain, limited suppliers, and hardly any engagement with a local university or research institute. In this case, the project could be viewed as a missed opportunity that REREC could have utilised specifically to focus on enhancing local skills and technical capacities, and/or supported synergies with local universities and similar repositories of knowledge to develop local capacities and strengthen the linkages of local industries. A locally active policy stance and the application of existing bargaining power, even if low, is key. It is interesting to note that Kenya has subsequently adopted a more active policy approach and has embedded local content ambitions into the newly passed energy bill (Kingiri and Okemwa, this volume).

Furthermore, the three cases emphasised the importance of the relative strength of the domestic supply base and how this needs to be considered in relation to the choice of technology (as discussed above). Our findings are aligned with the argument that co-benefits depend significantly on the capabilities of local firms engaged in green-technology manufacturing (Lema, Iizuka, and Walz, 2015). The manufacturing of most core technologies and components might be unlikely to take place in sub-Saharan Africa. However, there are a range of assembly tasks, as well as many services, that are being undertaken locally in the case of all three technologies examined here.

Investment decisions may benefit from a bottom-up approach to the selection of projects and technologies, considering first the range of activities that can easily be supplied locally (e.g., peripheral components such as solar-panel racks or wind-turbine foundations) and secondly those activities that are in the zone of proximate development, that is, where realistic capability-stretching may enable localisation (e.g., assembling turbine panels). However, the three cases 
all suggest that local involvement in strategic services, not least project management, is strategically important because it creates greater scope for influencing decisions concerning supply chains. Hence, the politically negotiated initiation stage of projects, where negotiations around financing may specify roles and responsibilities during the project-execution stage, is key (Hanlin, Okemwa, and Gregersen, 2019; Kirchherr and Urban, 2018). This may involve choice of technology and technology provider, as well as specifying the role of local actors and other conditions, which have a direct bearing on the creation of co-benefits.

\section{The nature and organisation of the investment project}

Our research showed that project organisation has important implications for economic co-benefit creation. In terms of the contractual arrangements, as mentioned already, the nature of tied finance had the knock-on effect of creating 'bundled projects' organised by Chinese EPCs. In Adama, the technical specifications of this project were quite clearly designed and influenced by the project developers, the financing, and the EPC contractors' terms. The origin of the technology was defined by the majority financial investment from China Exim Bank, while the lists of suppliers and technical equipment illustrate the preference for Chinese suppliers. Further favourable conditions were granted to the importation of equipment, with exemptions from both customs duties and taxes related to their import. However, negotiations on the part of the government of Ethiopia were designed to ensure local participation through the involvement of the universities and state-owned shipping companies.

Similarly, in the Bui project, the turnkey EPC contract that put Sinohydro in charge of its construction and operations had implications for the project's organisation. Some 60 relevant players were involved in the Bui Dam project overall, with Sinohydro responsible for its implementation and for organising its own supply chains.

In Garissa too there was a full-package provision of EPC contracts. Chinese developers made turnkey investments with significant imported content and frequent use of imported labour. The technical specifications of the project were designed and influenced by the project's EPC contractors and the financiers' terms and conditions. Further favourable terms were provided for any imported equipment with exemptions of both custom duties and taxes related to their import. To a large extent, the project was executed as a package 'parachuted' in from China, which limited the agency and influence that could be exerted by the national actors (Bhamidipati and Hansen, 2021).

The element of finance is significant because it shifts the relative bargaining power strongly in favour of the investor-contractor consortium. As a result, the co-benefits are largely dependent on the project developers that are engaged in making the key decisions concerning the project. However, there may be some scope for planned capacity-building in project negotiations. In the Garissa case, the project provided naturally occurring, learning-by-doing opportunities for skills 
development and for familiarising a host of Kenyan stakeholders with the solar PV technology, as well as with the processes entailed in designing and operating a utility-scale PV project. The beneficiaries included select REREC staff, Kenyan electricity firms (KPLC, KenGen, KETRACO), the Kenyan workers engaged with semi-skilled tasks, and the five Kenyan engineers hired for the O\&M phase on a contractual basis. The engineers benefitted directly from the training and acquisition of relevant skills (including technical, electrical, IT, and safety-related skills). The unskilled Kenyan workers secured temporary jobs and incomes, but they also performed the sorts of tasks that are generic to most construction projects. Importantly, however, the engagement of Maknes Consulting was an important step because it created a 'vessel' for the transfer of local capabilities and lessons from one project to the next. Nonetheless the overall turnkey model of the project involving mainly Chinese contractors, the centralised nature of project delivery, and the limited planned efforts to increase local capacity-building limited the scope for co-benefits.

The government of Ethiopia utilised a similar strategy, but went further in its decision to give universities the mandate to act as the owner's consultants with the aim of increasing technology transfers, as knowledge transfer defined the unique organisational arrangements of the Adama case. Bringing in universities as important actors in this situation is interesting and suggests the intention to develop industry-university linkages. It emphasises how universities can act as recipients of knowledge transfers in the innovation system. It also accentuates universities' roles in innovation systems, where a heterogeneous group of actors that are not firms are important in contributing to capability accumulation in terms of innovation, sustainability, and long-term dynamism. However, in practice, further studies need to be conducted to assess the quality of knowledge and technology transfer, as all parties in the Adama project mentioned challenges in the collaborative arrangements.

\section{Conclusions}

This chapter has set out to examine the type and nature of the local economic co-benefits that may arise from Chinese renewable-energy investments in subSaharan Africa. It contributes to a small but growing body of empirical research on the economic opportunities of implementing green transformations in latecomer countries. The existing literature on such economic opportunities (i.e., the potential co-benefits) has mainly focused on large 'emerging economies' with established programmes for renewable energy, comparably strong production, and innovation systems, and the pre-existing potential for a high degree of localisation of green economic activities, and even for exports of green technologies (Binz et al., 2017; Lema, Fu, and Rabellotti, 2020). Much less attention has been paid to low and lower-middle income countries where strategies and policies for greening with renewables are much more recent and where practical implementation is dependent on significant inflows of capital and technology. 
The chapter has sought to attend to this gap by focusing on specific renewableenergy investment projects in sub-Saharan Africa. Given the increasing Chinese involvement in renewable energy in this region, it was important to understand the extent, nature, and determinants of the resulting co-benefits when projects are organised by Chinese renewable-energy developers. Since this push for cobenefits, although increasing, is still in its infancy, its insights are to be derived mainly from case studies of pioneer projects.

\section{Main findings and policy implications}

The project-level analysis in this chapter suggests that the projects examined made some contributions to the local economies, but it is necessary to emphasise the highly restricted nature of the benefits we identified. Hence, we stress the need for caution when it comes to overly optimistic expectations of co-benefits arising from investments in renewable-energy infrastructure projects in sub-Saharan Africa.

In a broader perspective, the findings of this chapter highlight the significant challenges associated with the notion of green latecomer development and sustainable industrialisation in sub-Saharan Africa. In the context of latecomer development, such a strategy may be easier to achieve in upper-middle income 'emerging economies' compared to low income or lower-middle income countries with more limited institutional capabilities. This chapter has shed light on substantially different settings, where growth and development-enhancing objectives are rather difficult to achieve through large green infrastructure projects. This is not least because of the geographical separation, unequal distribution of capabilities, and skewed power relations between the users and producers of green infrastructure in Africa.

This does not mean that green latecomer development should be abandoned as a strategy in countries like Kenya, Ethiopia, and Uganda. On the contrary, it means that, at least in the context of the provision of green energy infrastructure, green latecomer development needs to be stepped up to become effective: an active and directed policy approach needs to be devised for maximising the co-benefits of further renewable energy investments in the future. To unfold this insight further, we connect insights from our findings with three pertinent policy issues.

First, while we find evidence of benefits, these benefits, however limited, did not emerge as automatic by-products of the investments. Every green investment decision needs to be preceded by exerting the full extent of the available bargaining power. Local bargaining power is often constrained, but it is not non-existent. This can ensure the maximum possible local content, jobs in knowledge-intensive tasks, and deliberately designed transfers of knowledge and capabilities from existing foreign suppliers of green infrastructure (Chinese or otherwise) to African users and associated local enterprises and organisations in local systems of production. While this point may seem obvious, there are indications that major investment decisions have been made mainly with the primary benefits in mind (i.e., reducing carbon emissions) and without paying 
sufficient attention to the strategic opportunities to achieve the associated economic co-benefits.

Second, these policies and strategies should focus deliberately on opportunities in the process of delivering these green infrastructure projects. There is a tendency to neglect this stage while focusing too much on the processes of delivering sustainable energy. For example, the cases analysed show that, while there were quite significant transfers of knowledge through training and overseas secondment related to operations and routine maintenance (i.e., the service delivery process), there was no correspondingly significant and deliberate transfer of capabilities related to the preceding infrastructure delivery process. Accordingly, the ambition needs to take the form of the gradual building of local capabilities related to the latter. If the greening of local energy systems is to be beneficial to local economic development, it is not sufficient to say, as is sometimes done in investor and climate change circles, that it does not matter who creates the infrastructure as long as it is green and cost-efficient. Our findings indicate that significant co-benefits will only arise with substantial local involvement in the high value-adding and more knowledge-intensive stages of the infrastructure delivery process.

Third, green energy infrastructure should not be treated in isolation in this respect. While these types of projects could become important learning and development platforms, the attainment of infrastructure project execution capabilities is relevant outside this specific domain, that is, in building roads, ports, electricity distribution systems etc. as well. Interestingly, in all three cases, independent local entities were assigned to the role of the owners' consultants. These entities could become important vessels for local transfers of lateral capabilities from one project to the next. However, due to the strategic importance of these capabilities and their national public-good nature, they may also need to be located in government offices.

\section{Acknowledgements}

The authors gratefully acknowledge the Danish Ministry of Foreign Affairs (Grant: DFC 14-09 AAU) for providing funding support for the IREK research on which this chapter is based. The authors would also like to thank all the participants of the IREK Workshop, held in Nairobi in 2019, in particular Rob Byrne and Helene Ahlborg for their invaluable comments and inputs.

\section{Notes}

1 A longer article version of this book chapter is currently under review in the Journal World Development.

2 As Shen (2020) emphasises, it is difficult to obtain a precise estimate of the size of and trends in Chinese activities in the power sector in sub-Saharan Africa. This reflects a larger problem regarding data shortcomings on funding from China because China has not released a breakdown of its lending activities. 
3 The RE projects were chosen in three SSA countries: the Adama project in Ethiopia (wind energy), the Bui Dam project in Ghana (hydro energy), and the Garissa project in Kenya (Solar PV). The core of our analysis thus builds on primary data obtained at the project level. This information was used for micro-level analyses exploring inbound flows, local conditions, the characteristics of organisational arrangements, and the three main types of co-benefit. The main sources of information for these case studies are site visits at each project and a total of 38 in-depth interviews with project organisers and key informants. Given the lack of existing studies, the chapter provides a first exploratory attempt to analyse the co-benefits and their determinants in Chinese projects.

4 Five of these companies combined are responsible for three-quarters of the total generating capacity between 2010 and 2015 in SSA (IEA, 2016).

5 Previously, the French consulting firm Coyne et Bellier had produced the dam design, and the British consultancy Environmental Resources Management (ERM) had conducted the Environmental and Social Impact Assessment (ESIA).

6 REREC is a government organisation mandated to spearhead and drive renewable energy development along with rural electrification in Kenya.

7 Furthermore, additional local employment during O\&M is to be generated in the form of security guards, solar-panel cleaners, and general cleaners for the project site spread over 85 hectares.

\section{References}

Ajakaiye, O. and Kaplinsky, R. (2009) 'China in Africa: A relationship in transition', European Journal of Development Research, 21(4), pp. 479-484. https://doi.org/10.1057 /ejdr.2009.30

Baker, L. and Sovacool, B.K. (2017) 'The political economy of technological capabilities and global production networks in South Africa's wind and solar photovoltaic (PV) industries', Political Geography, 60, pp. 1-12. https://doi.org/10.1016/j.polgeo.2017.03.003

Bhamidipati, P.L. and Hansen, U. (2021) 'Unpacking China-Africa relations and local agency: Frictional encounters in the transition to solar power in Kenya', Geoforum, 119, 206-217.

Binz, C., Gosens, J., Hansen, T. and Hansen, U. (2017) 'Toward technology-sensitive catching-up policies: Insights from renewable energy in China', World Development, 96, pp. 418-437. https://doi.org/10.1016/j.worlddev.2017.03.027

Chirambo, D. (2018). Towards the achievement of SDG 7 in sub-Saharan Africa: Creating synergies between Power Africa, Sustainable Energy for All and climate finance in-order to achieve universal energy access before 2030. Renewable and Sustainable Energy Reviews, 94, 600-608.

Flyvbjerg, B., Holm, M.S. and Buhl, S. (2002) 'Underestimating costs in public works projects: Error or lie?', Journal of the American Planning Association, 68(3), pp. 279-295. https://doi.org/10.1080/01944360208976273

Ghana Web. (2017) 'Bui dam generates $\$ 335.7 \mathrm{~m}$ revenue', Ghana Web, 12 December. Available at: https://www.ghanaweb.com/GhanaHomePage/business/Bui-dam -generates-335-7m-revenue-608901 (Accessed: 09/10/2020).

Hanlin, R., Okemwa, J. and Gregersen, C. (2019) 'Building competences and capabilities through projects: Examples from Kenya's renewable energy sector', IREK Working Paper No. 8. Available at: https://www.irekproject.net/wp-content/uploads/IRE KPaper8.pdf

International Energy Agency (IEA). (2016) Boosting the Power Sector in Sub-Saharan Africa: China's Involvement. Paris: International Energy Agency. 
IEA (2020) Africa Energy Outlook. Paris: International Energy Agency.

International Renewable Energy Agency (IRENA) (2013) Africa's Renewable Future: The Path to Sustainable Growth. Abu Dhabi: International Renewable Energy Agency.

IRENA (2019) Scaling Up Renewable Energy Deployment in Africa. Abu Dhabi: International Renewable Energy Agency.

Kaplinsky, R. and Morris, M. (2009) 'Chinese FDI in Sub-Saharan Africa: Engaging with large dragons', The European Journal of Development Research, 21(4), pp. 551-569. https://doi.org/10.1057/ejdr.2009.24

Kirchherr, J. and Urban, F. (2018) 'Technology transfer and cooperation for low carbon energy technology: Analysing 30 years of scholarship and proposing a research agenda', Energy Policy, 119, pp. 600-609. https://doi.org/10.1016/j.enpol. 2018.05.001

Lema, R., Iizuka, M. and Walz, R. (2015) 'Introduction to low-carbon innovation and development: Insights and future challenges for research', Innovation and Development, 5(2), pp. 173-187. https://doi.org/10.1080/2157930X.2015.1065096

Lema, R., Fu, X. and Rabellotti, R. (2020) 'Green windows of opportunity? Latecomer development in the age of transformation towards sustainability', Industrial and Corporate Change, 29(5), pp. 1193-1209. https://doi.org/10.1093/icc/dtaa044

McCrudden, C. (2004) 'Using public procurement to achieve social outcomes', Natural Resources Forum, 28(4), pp. 257-267. https://doi.org/10.1111/j.1477-8947.2004. 00099.x

Power, M., Newell, P., Baker, L., Bulkeley, H., Kirshner, J. and Smith, A. (2016) 'The political economy of energy transitions in Mozambique and South Africa: The role of the Rising Powers', Energy Research and Social Science, 17, pp. 10-19. http://dx.doi.org /10.1016/j.erss.2016.03.007

Sanfilippo, M. (2010) 'Chinese FDI to Africa: What is the nexus with foreign economic cooperation?’ African Development Review, 22, pp. 599-614. https://doi.org/10.1111/j .1467-8268.2010.00261.x

Schmidt, T. S. and Huenteler, J. (2016) 'Anticipating industry localization effects of clean technology deployment policies in developing countries', Global Environmental Change, 38, pp. 8-20. https://doi.org/10.1016/j.gloenvcha.2016.02.005

Shen, W. (2020) 'China's role in Africa's energy transition: A critical review of its intensity, institutions, and impacts', Energy Research and Social Science, 68, p. 101578. https://doi.org/10.1016/j.erss.2020.101578

Shen, W. and Power, M. (2016) 'Africa and the export of China's clean energy revolution', Third World Quarterly, 6597(July), pp. 1-20. https://doi.org/10.1080/01436597.2016. 1199262

Silvestre, B.S. (2015) 'Sustainable supply chain management in emerging economies: Environmental turbulence, institutional voids and sustainability trajectories', International Journal of Production Economics, 167, pp. 156-169. https://doi.org/10.1016 /j.ijpe.2015.05.025

Sperling, F., Granoff, I. and Vyas, Y. (2012) Facilitating Green Growth in Africa. Tunis: African Development Bank.

Tan-Mullins, M., Urban, F. and Mang, G. (2017) 'Evaluating the behaviour of chinese stakeholders engaged in large hydropower projects in Asia and Africa', The China Quarterly, 230, pp. 464-488. https://doi.org/10.1017/S0305741016001041

Wegenast, T., Krauser, M., Strüver, G. and Giesen, J. (2019) 'At Africa's expense? Disaggregating the employment effects of Chinese mining operations in sub-Saharan Africa', World Development, 118, pp. 39-51. https://doi.org/10.1016/j.worlddev.2019. 02.007 